\title{
Pseudoalteromonas piscicida X-8 causes bleaching disease in farmed Saccharina japonica
}

\author{
Xiaoyang Zhang ${ }^{\mathrm{a}}$, Yao Chen ${ }^{\mathrm{a}}$, Mahasweta Saha ${ }^{\mathrm{b}}$, Yingrui Zhuang ${ }^{\mathrm{a}}$, Lirong Chang ${ }^{\mathrm{c}}$, \\ Luyang Xiao $^{c}$, Gaoge Wang ${ }^{\text {a,** }}$ \\ ${ }^{a}$ College of Marine Life Sciences and Institute of Evolution \& Marine Biodiversity, Ocean University of China, Qingdao 266003, China \\ ${ }^{\mathrm{b}}$ Marine Ecology and Biodiversity, Plymouth Marine Laboratory, Prospect Place, PL1 3DH Plymouth, United Kingdom \\ ${ }^{\mathrm{c}}$ Weihai Changqing Ocean Science \& Technology Co., Ltd, Rongcheng 264316, China
}

\section{A R T I C L E I N F O}

\section{Keywords:}

Bleaching disease

Pathogenic bacteria

Pseudoalteromonas piscicida X-8

Saccharina japonica

\begin{abstract}
A B S T R A C T
Saccharina japonica is a commercially farmed seaweed of global importance. However, disease occurrence during different stages of cultivation can result in substantial economic losses. Identification of the causative agents of disease remains a significant bottleneck to the large scale cultivation of $S$. japonica. In this study, an aerobic heterotrophic, flagellated, rod-shaped Gram-negative bacterial strain X-8 was isolated from the bleaching diseased $S$. japonica sporelings. Pathogenecity of strain X-8 was tested by re-infection assay. The ultrastructural changes of infected $S$. japonica cells by strain X-8 indicated that chloroplasts were the first organelle responding to X-8 infection with deformed structure and later followed by fragmented nucleus. However, the ultra-structure of mitochondria and cell wall remained intact during the re-infection. Based on 16S rRNA gene sequence, morphological and biochemical characteristics, strain X-8 was designated as Pseudoalteromonas piscicida X-8. The pathogenicity of $P$. piscicida X-8 was identified by Koch's Postulate under laboratory conditions. Our results will not only help to establish a stable experimental model between the pathogenic bacteria and the host $S$. japonica to further elucidate the virulence mechanisms, but will also provide information for disease management to effectively prevent and mitigate the occurrence of bleaching disease of $S$. japonica at nursery stage.
\end{abstract}

\section{Introduction}

Seaweed diseases have increased recently with the global climate change (Zhang et al., 2020). It has been identified that various pathogens like bacteria, viruses, fungi and other eukaryotes are the causative agents for various macroalgal diseases (Gachon et al., 2010; Wang et al., 2014). Isolation and identification of pathogenic organisms is of priority importance for the disease diagnosis and identification of virulence mechanisms.

Bleaching disease frequently occurs in both wild and farmed seaweeds (Egan et al., 2014; Weinberger et al., 1994, 1997). So far, identification of pathogenic bacteria (Neil et al., 2011; Egan et al., 2013) and investigation of virulence mechanisms (Melissa et al., 2015a; Melissa et al., 2015b; Hudson et al., 2018) have been well-studied for the bleaching disease in the wild red seaweed Delisea pulchra. Tip bleaching disease was firstly reported in commercially cultivated agar-producing seaweed Gracilarja conferta in Israel (Weinberger et al., 1994). Disease symptoms included white necrotic tissues followed by thallus fragmentation. Corynebacterium-Arthrobacter and Flavobacterium-Cytophaga were identified as the pathogenic bacteria for the tip bleaching disease (Weinberger et al., 1994, 1997). Further, Alteromonas sp. was found to be the pathogenic bacteria for thallus bleaching disease in brown seaweed Laminaria religiosa and could induce disease in axenic L. religiosa with deterioration and lesions on the thallus cellular layer (Vairappan et al., 2001). By combining 16S rDNA sequence analysis and biochemical characterization, Sun et al. (2012) reported that Thalassospira sp. and Vibrio parahaemolyticus caused tip bleaching in healthy Gracilariopsis lemaneiformis. Although pathogenic bacteria were identified in the above commercially cultivated seaweeds, so far no virulence mechanisms of the pathogenic bacteria were elucidated.

Saccharina japonica (synonymous of Laminaria japonica) is one of the most important commercially farmed seaweeds worldwide (Tseng, 1994; FAO, 2016). China contributes $60 \%$ of $S$. japonica production and $90 \%$ of alginate globally (FAO, 2016; Wang et al., 2014). Like the land crops, S. japonica suffers from various diseases at both nursery stage and in the field cultivation. Chinese researchers have made efforts on

\footnotetext{
* Corresponding author.

E-mail address: wgaoge@ouc.edu.cn (G. Wang).
} 
isolation and identification of pathogenic bacteria triggering various diseases at nursery stage. Green rot/falling off disease was the most destructive disease at nursery stage of $S$. japonica (Tseng, 1962, 1985; Ding, 1992). During the occurrence of green rot/falling off disease, the sporelings were found to turn greenish and eventually turned soft and decayed. Finally, the sporelings fell off from the nursery substrata (Zhang et al., 1962; Wang et al., 2014). Alginic acid-decomposing bacteria were the potential pathogenic bacteria for the green rot/falling off disease (Chen et al., 1979, 1981). Alginic acid-decomposing bacteria were not a taxonomic terminology, but were referred to all of the bacteria which were capable of degrading alginate (Chen et al., 1979; Xiang, 2001), the main components of the cell wall of $S$. japonica. In addition, sulphate reducing bacteria and hydrogen sulphide-producing saprophytic bacteria, for example, Micrococcus, induced the malformation disease of sporelings which could make the sporelings die and drop off the nursery substrata (Wu, 1990). Thick stip-curl thallus disease was reported at the nursery stage of $S$. japonica and bacteroids were the pathogenic bacteria (Xiang, 2001). Sea water quality and bacterial infection can cause spot-rot disease at nursery stages (Xiang, 2001). Although some bacteria have been identified as the pathogenic bacteria responsible for various diseases, the virulence mechanisms haven't been investigated (Wang et al., 2014).

Recently, bleaching disease frequently occured during the nursery stage of farmed $S$. japonica ( $S$. japonica farm's communication). When the bleaching disease occurred, the tips (far from the meristematic tissue) of the sporelings turned white and rotted, and finally the bleaching tissue fell off from the thalli ( $S$. japonica farm's communication). Besides, compared to the healthy tissue, microscopic observations showed the tissue color of the bleaching-diseased sporelings was white and the chloroplasts gathered around the cell wall. Therefore, in this study, we aimed to isolate and identify the pathogenic bacteria responsible for the bleaching disease of sporelings by culture-dependent method, reinfection assay, 16S rRNA gene sequence and biochemical characterization. The results of this study will not only help to construct a stable experimental model between the pathogenic bacteria and the host $S$. japonica for further investigating the virulence mechanisms, but will also provide theoretical support for the disease management to prevent and mitigate the bleaching disease at nursery stage.

\section{Materials and methods}

\subsection{Sample collection}

Bleaching diseased sporelings $(10-20 \mathrm{~mm})$ were collected from Rongcheng nursery of $S$. japonica $\left(122^{\circ} 35^{\prime} 56.13^{\prime \prime} \mathrm{N}, 37^{\circ} 12^{\prime} 36.49^{\prime \prime} \mathrm{E}\right)$ in Shandong Province, China on October 20, 2018. Diseased sporelings were stored in a sampling box with ice packs and were transported to the laboratory in Qingdao within $4 \mathrm{~h}$.

\subsection{Bacterial isolation}

Bacterial strains were isolated from the bleaching diseased sporelings by traditional culture-dependent method immediately after the bleaching diseased sporelings reached laboratory. Diseased sporelings were rinsed with sterilized filtered seawater (salinity: 30\%o) at least three times to remove the loosely attached epiphytes. Then the diseased sporelings were cut into pieces with aseptic scissors and grinded to homogenate with aseptic mortar. After that, the homogenate was diluted with tenfold dilution method (Ying et al., 2019) and then $120 \mu \mathrm{L}$ of each homogenate was spread on Zobell $2216 \mathrm{E}$ marine agar (Oppenheimer, 1952) and was cultured for $24 \mathrm{~h}$ at $25^{\circ} \mathrm{C}$. Distinct bacterial colonies were selected according to morphological characteristics, such as shape and pigment. Isolated strains were purified by re-streaking on the new Zobell $2216 \mathrm{E}$ marine agar at least for three times. The purified bacterial strains were stored at $-80{ }^{\circ} \mathrm{C}$ with $30 \%(v / v)$ glycerin for further use.

\subsection{Re-infection assay}

Before the re-infection assay, the isolated bacteria were activated according to the following operations. Firstly, the stored bacteria were brought back to room temperature. Then, $20 \mu \mathrm{L}$ of the bacteria were streaked on the Zobell $2216 \mathrm{E}$ marine agar plates and were cultured at $25{ }^{\circ} \mathrm{C}$ for $8 \mathrm{~h}$. After that, single colony was selected and was inoculated into $100 \mathrm{~mL}$ fresh Zobell $2216 \mathrm{E}$ liquid medium and was cultured using a shaker incubator at $25{ }^{\circ} \mathrm{C}$ with $120 \mathrm{rpm}$ for $8 \mathrm{~h}$. Then subculture was processed by re-inoculating $1 \mathrm{~mL}$ of the bacterial culture into $100 \mathrm{~mL}$ of fresh Zobell 2216E liquid medium until the optical density at $\mathrm{OD}_{600}$ reached $\sim 0.5\left(1.0 \times 10^{8}\right.$ colony forming units $\left.(\mathrm{CFU}) / \mathrm{mL}\right)$, so that the culture was in exponential growth phase.

Pathogenicity of each isolated bacterial strain was tested by reinfection assay. The healthy juvenile sporophytes $(30-40 \mathrm{~cm}$ in length) were collected from Weihai Changqing Ocean Science \& Technology Co., Ltd., Rongcheng, Shandong province, China, on December 10, 2018 and were transported to lab within $4 \mathrm{~h}$. Epiphytes were removed by rinsing with sterilized filtered seawater at least three times and then the edge of the thalli were cut into a small section $(1.0 \times 1.0$ $\mathrm{cm}^{2}$ ) with sterile surgical blade. The small sections were placed into the individual wells of 24-well plate. The infected group consisted of the small section of thalli in $1 \mathrm{~mL}$ of the isolated bacterial liquid (bacterial density: $1.0 \times 10^{8} \mathrm{CFU} / \mathrm{mL}$ ). For the control group, only $1 \mathrm{~mL}$ of Zobell $2216 \mathrm{E}$ liquid medium was added to the small section of the thalli. Finally, the 24-well plates were incubated in a light incubator at $10 \pm$ $0.5{ }^{\circ} \mathrm{C}$ with $60 \mu \mathrm{E} \mathrm{m}^{2} \mathrm{~s}^{-1}$ for $24 \mathrm{~h}$ or $72 \mathrm{~h}$ (for scanning/transmission electron microscope). The incubating condition was similar to that of the nursery farm. During the $24 \mathrm{~h}$ of incubation, the inoculated tissues were collected and observed under light microscope (Nikon, Japan) at $12 \mathrm{~h}$ and $24 \mathrm{~h}$, respectively. Replication level was 8 for both control and the infected groups.

\subsection{Observations of scanning electron microscope (SEM) and ultrastructural changes of the infected juvenile sporophytes by transmission electron microscope (TEM)}

$R e$-infection experiments were conducted following the methods described in Section 2.3, except that the healthy juvenile sporophytes with $50-70 \mathrm{~cm}$ in length were used for re-infection assay. Control and infected tissues were collected at $10 \mathrm{~h}, 30 \mathrm{~h}, 52 \mathrm{~h}$, and $72 \mathrm{~h}$ after being infected with the pathogenic bacterial strains. The preparation sections for SEM was processed as follows: both control and the infected tissue sections were fixed in $3 \%$ gluteraldehyde for $3 \mathrm{~h}$ and then were rinsed three times for $30 \mathrm{~min}$ each time with $0.1 \mathrm{M}$ PSB. Further, the samples were dehydrated for $30 \mathrm{~min}$ intervals each in 50, 70, 80, 90\% and $100 \%$ ethanol for 30 min each time. Finally, the samples were critical-point dried and gold-coated. The samples were observed under electron microscope JOUQDSM-840 (JEOL, Japan).

Sections for TEM were prepared as follows: the collected samples were fixed in $2.5 \%$ glutaraldehyde at $4{ }^{\circ} \mathrm{C}$ for $4 \mathrm{~h}$ and then were washed with $0.1 \mathrm{M}$ PBS three times for $10 \mathrm{~min}$ each time. After $1 \%$ osmium tetroxide $\left(\mathrm{OsO}_{4}\right)$ treatment at $40{ }^{\circ} \mathrm{C}$ for $2 \mathrm{~h}$, then rinsed again with $0.1 \mathrm{M}$ PBS buffer three times for $10 \mathrm{~min}$ each time. The samples went through graded series of ethanol/water (30\%, 50\%, 70\%, 90\% and 100\%) for 10 min at each concentration, except $100 \%$ was twice (Maurin et al., 1993). Then, the samples were fixed with spur's epoxy resin and polymerized for $24 \mathrm{~h}$ at $37^{\circ} \mathrm{C}, 45^{\circ} \mathrm{C}, 65^{\circ} \mathrm{C}$ respectively. The samples were sliced into ultrathin sections, which were immersed in lead nitrate and uranyl acetate for $15 \mathrm{~min}$, respectively. Finally, the ultrathin sections were observed and measured by using the JEM-1200EX TEM microscope (JEOL, Japan).

Replication level was three for both control and the infected groups for both SEM and TEM samples, respectively. 


\subsection{Morphological observation of the pathogenic bacterial strain}

Morphological characteristics (namely colony shape, pigmentation) of the pathogenic bacteria were determined visually on Zobell $2216 \mathrm{E}$ marine agar after being cultured at $25^{\circ} \mathrm{C}$ for $24 \mathrm{~h}$. The cell morphology was characterized by applying both negative staining TEM and ultrathin section TEM. For preparation of negative staining samples, the pathogenic strains were cultured at Zobell $2216 \mathrm{E}$ marine broth at $25^{\circ} \mathrm{C}$ for 24 $\mathrm{h}$. Then, the bacterial liquid was centrifuged at $13000 \mathrm{~g}$ for $30 \mathrm{~min}$ at $4{ }^{\circ} \mathrm{C}$ to obtain the precipitate, which was immersed in $3.0 \%$ glutaraldehyde for $10 \mathrm{~min}$. A small drop of the suspension was put on a carbon coated copper grid $(w / v)$ for $3 \mathrm{~min}$, following dried for $15 \mathrm{~min}$ at room temperature. Sample was examined under JEM 1200EX (JEOL, Japan) for TEM.

With respect to the TEM ultrathin sections, preparation of bacterial precipitate was the same as negative staining. Bacterial precipitate was fixed with $2.5 \%(\mathrm{w} / \mathrm{v})$ glutaraldehyde at $40^{\circ} \mathrm{C}$ for $4 \mathrm{~h}$ and was rinsed with $0.1 \mathrm{M}$ PBS at $10 \mathrm{~min}$ intervals for three times. Then the samples were fixed in $1 \%$ of osmic acid at $40{ }^{\circ} \mathrm{C}$ for $2 \mathrm{~h}$ and were rinsed with 0.1 M PBS at $10 \mathrm{~min}$ intervals for three times. After that the samples were dehydrated with ethanol gradient concentration of $30 \%, 50 \%, 70 \%$, $80 \%$ for $10 \mathrm{~min}$ intervals and $100 \%$ for $10 \mathrm{~min}$ twice. Finally, the samples were embedded in Epon812 Epoxy resin and were incubated at $37^{\circ} \mathrm{C}, 45^{\circ} \mathrm{C}$ and $65^{\circ} \mathrm{C}$ each for $2 \mathrm{~h}$. Ultrathin sections were prepared by UltracutE machine and were stained with lead nitrate and uranyl acetate for 15 min. Ultrathin sections were observed under JEM 1200EX (JEOL, Japan) for TEM.

\subsection{Amplification and sequencing of the $16 S$ rRNA gene and phylogenetic analysis}

Total DNA of pathogenic bacterial strains was extracted using the HiPure Soil DNA Kits (Magen, Guangzhou, China), the universal primers 27F (5'-AGAGTTTGATCMTGGCTCAG-3') and 1492R (5'-TACGGYTACCTTGTTACGACTT-3') (Weisburg et al., 1991). PCR amplification system was performed in triplicate of $50 \mu \mathrm{L}$ mixture containing $5 \mu \mathrm{L}$ of $10 \times$ KOD Buffer, $5 \mu \mathrm{L}$ of $2.5 \mathrm{mM}$ dNTPs, $2 \mu \mathrm{L}$ of each primer $(5 \mu \mathrm{M}), 1$ $\mu \mathrm{L}$ of KOD Polymerase, $5 \mu \mathrm{L}$ of template DNA and $22 \mu \mathrm{L}$ of double distilled water. The PCR program was as followings: denaturation at $94^{\circ} \mathrm{C}$ for $6 \mathrm{~min}$, followed by 27 cycles at $98^{\circ} \mathrm{C}$ for $10 \mathrm{~s}, 62^{\circ} \mathrm{C}$ for $30 \mathrm{~s}$ and $68^{\circ} \mathrm{C}$ for $30 \mathrm{~s}$ and a final extension at $68^{\circ} \mathrm{C}$ for $10 \mathrm{~min}$. Amplicons were run on $2 \%$ agarose gel. Purification of the amplicon followed the instructions of AxyPrep DNA Gel Extraction Kit (Axygen Biosciences, Union City, CA, USA). The purified amplicons were sequenced $(2 \times 250)$ on the Illumina platform with the standard protocol. The $16 \mathrm{~S}$ rRNA gene sequences of the pathogenic bacterial strains were deposited in the NCBI database.

According to the EzBioCloud server (http://www. ezbiocloud. net) (Khalifa and Bekhet, 2017), the pairwise similarity values of the pathogenic strain and its closely related bacterial strains were calculated. The 16S rRNA gene sequences of related pathogenic bacterial strains were retrieved from the NCBI database (http://www. ncbi. nlm. Nih. gov). All of them were aligned by using the CLUSTAL X (Larkin et al., 2007). Under mega version $X$ (Kumar et al., 2018), phylogenetic trees were reconstructed based on the neighbour - joining (NJ) (Saitou and Nei, 1987). For NJ tree, the Kimura two- parameter model was chosen (Kimura, 1980). The robustness of each topology was checked by 1000 bootstrap replications.

\subsection{Analysis of average nucleotide identity (ANI)}

In order to identify the pathogenic bacterial strain accurately, we further conducted the analysis of ANI. Pairwise comparison of ANI between pathogenic bacterium and its type species was analyzed based on BLAST+ (ANIb) from JSpeciesWSc (Richter et al., 2015). The two species were considered to be the same species when the value of ANI was $\geq 95 \%$

2.8. Characterization of the pathogenic bacterial strain under Biolog Gen III microtest system

Biochemical and physiological characterization of the pathogenic strains were evaluated by Biolog Gen III microtest system (Biolog, Hayward, CA, USA) according to the manufacturer's protocol. Pathogenic bacterial strains were cultured in Zobell $2216 \mathrm{E}$ marine agar at $25^{\circ} \mathrm{C}$ for $24 \mathrm{~h}$ and then pathogenic bacterial colonies were re-suspended to the Biology fluid A until the turbidity of fluid A was $98 \%$ with a turbidimeter (Biology TM). $100 \mu \mathrm{L}$ culture bacteria were inoculated into each well of Gen III MicroPlate. After incubation at $25^{\circ} \mathrm{C}$ for $24 \mathrm{~h}$, the results were collected at $600 \mathrm{~nm}$ automatically by the standardized Micro station TM system (Biolog Inc., USA). Two wells were designed set as negative and positive controls by remaining color less and purple, respectively.

\section{Results}

\subsection{Symptoms of bleaching disease and microscopic observations}

Symptoms of bleaching diseased sporelings exhibited white tips (far from the meristematic tissue), which finally fell off from the thalli (Fig. 1 A, black arrows-indicated area). Compared to the healthy tissue (Fig. 1 B), microscopic observations showed that the color of the bleached diseased tissue was white, and the chloroplasts assembled around the cell wall (Fig. 1 C, black arrows).

\subsection{Isolation of the pathogenic bacteria and pathogenicity test by re- infection assay}

Ten bacterial strains were isolated and purified from the bleaching diseased sporelings. Only isolated strain X-8 caused the bleaching disease in healthy juvenile sporophytes (Fig. $2 \mathrm{~A}$ ). Compared to the control mimicked with sterilized seawater at $12 \mathrm{~h}$ and $24 \mathrm{~h}$ (Fig. $2 \mathrm{~B}, \mathrm{C}$ ), respectively, X-8 infected tissue with a density of $1.0 \times 10^{8} \mathrm{CFU} / \mathrm{mL}$ turned white to some extent at $12 \mathrm{~h}$ (Fig. $2 \mathrm{D}$ ), and became totally white at $24 \mathrm{~h}$ (Fig. $2 \mathrm{E}$ ). Assemblage of chloroplasts (black arrows in Fig. $2 \mathrm{D}$, E) near the cell wall was also observed in the X-8-infected cells at $12 \mathrm{~h}$ and $24 \mathrm{~h}$, respectively. Disease symptoms caused by X-8 were the same as those symptoms observed in the individuals collected from the nursery farm.

\subsection{Observations of SEM and ultrastructural changes of infected tissue by strain $X-8$}

The normal morphology of healthy tissue of juvenile sporophytes looked smooth with clear cell morphology (Fig. 3 I). In the control experiment, SEM observations showed the cells shrank on the surface of tissue. Cell shrinkage became more prominent at $52 \mathrm{~h}$ and $72 \mathrm{~h}$ (Fig . $3 \mathrm{C}$ and D), respectively. However, there were more pathogenic bacteria on the surface of the infected tissue with no clear cell morphology at $10 \mathrm{~h}$, $30 \mathrm{~h}, 52 \mathrm{~h}$ and $72 \mathrm{~h}$, respectively (Fig. 3 E, F, G, H).

The normal morphology of chloroplasts, nucleus, mitochondria and cell wall was showed in Fig. $4 \mathrm{I}$. Compared to the control group at $10 \mathrm{~h}$ (Fig. 4 A), $30 \mathrm{~h} \mathrm{(Fig.} \mathrm{4} \mathrm{B),} 52 \mathrm{~h}$ (Fig. 4 C) and 72 h (Fig. 4 D), respectively, the structure of chloroplasts and their thylakoids became deformed at $10 \mathrm{~h}$ after infected by strain X-8 (Fig. $4 \mathrm{E}$ ). While, the structure of nucleus and mitochondria remained intact (Fig. 4 E). Ultrastructure of chloroplasts and thylakoids disappeared and nucleus deformation begun at 30 $\mathrm{h}$ after infection with X-8 (Fig. 4 F). However, the outer membrane of chloroplasts and the nuclear membrane began to dissolve and nucleus became fragmented at $52 \mathrm{~h}$ (Fig. $4 \mathrm{G}$ ). The chloroplasts, the thylakoids and the nucleus were disintegrated and the boundary between the organelles was not obvious at $72 \mathrm{~h}$ after infection (Fig. $4 \mathrm{H}$ ). During the re- 


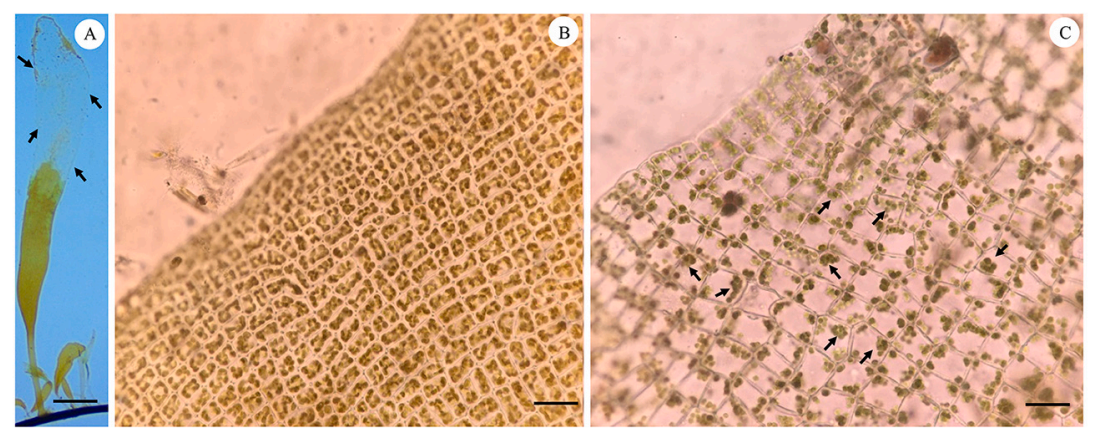

$12 \mathrm{~h}$

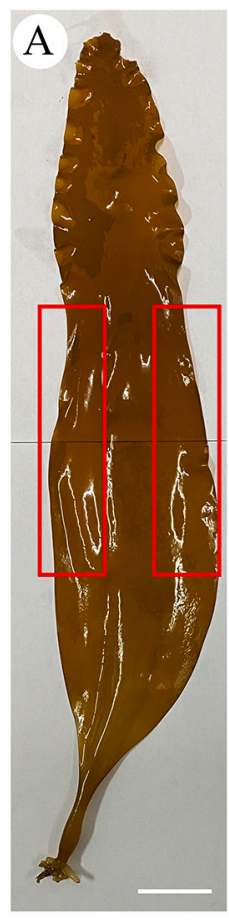

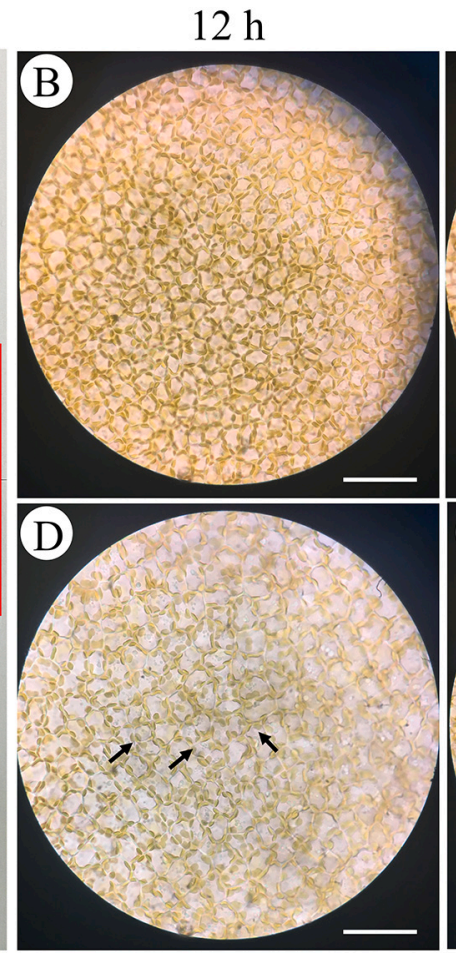

$24 \mathrm{~h}$

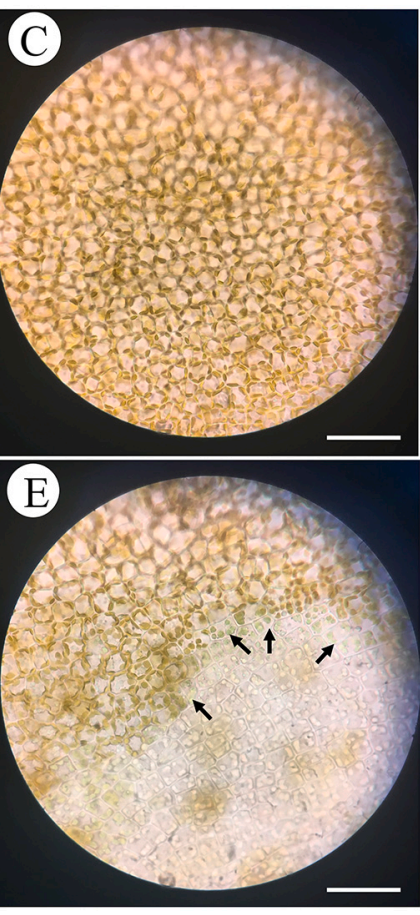

Fig. 1. Bleaching diseased sporelings and macroscopic observations of the healthy and diseased tissue.

A: bleaching diseased sporelings of $S$. japonica cultivated in the substrata, showing the white tip section (black arrows indicated area); B: healthy tissue; C: bleaching diseased tissue, black arrows indicated the assembled chloroplast near the cell wall.

Bars: $A=200 \mu \mathrm{m} ; \mathrm{B}$ and $\mathrm{C}=50 \mu \mathrm{m}$.
Fig. 2. Re-infected assay of healthy juvenile sporophytes by strain X-8.

A: healthy juvenile sporophytes for re-infection assay, red framed thalii were used for re-infection assay; B and C: healthy juvenile sporophytes mimicked with sterilized seawater at 12 and $24 \mathrm{~h}$, respectively. C and D: re-infected tissue by strain X-8 at $12 \mathrm{~h}$ and $24 \mathrm{~h}$ respectively. Black arrows indicated the assemblage of chloroplasts near the cell wall.

Bars, A: $2 \mathrm{~cm}$; B, C, D and E: $150 \mu \mathrm{m}$. infection, the structure of mitochondria and cell wall remained intact all the time.

\subsection{Morphological characteristics of strain $X-8$}

The colonies of strain X-8 on Zobell 2216E agar media were yellow and moist with neat edges (Fig. $5 \mathrm{~A}$ ). Negative staining TEM indicated that strain X-8 was rod-shaped and was $0.5-1.0 \mu \mathrm{m}$ wide and $1.0-2.0 \mu \mathrm{m}$ long with a single polar flagellum (Fig. $5 \mathrm{~B}$ ). The ultrastructure of strain $\mathrm{X}-8$ was clear. The nuclear area in the cell could be clearly distinguished, and the nuclear region is scattered and not congregate (Fig. 5 C).

\subsection{Molecular identification and phylogenetic analysis}

The partial 16S rRNA gene sequence (1398 bp) of strain X-8 was uploaded to GenBank with accession numbers MH744667. Neighbourjoining phylogenetic tree was constructed based on 16S rRNA gene sequences, showing the phylogenetic positions of strain X-8 and the related Pseudoalteromonas species. The strain X-8 was most closely to Pseudoalteromonas piscicida JCM20779 ${ }^{\mathrm{T}}$ with $99.86 \%$ similarity (Fig. 6). Analysis of average nucleotide identity (ANI) between strain X-8 and Pseudoalteromonas piscicida JCM $20779^{\mathrm{T}}$ was $96.23 \%$.
3.6. Biochemical characterization of X-8 using biolog gen III microtest system

Strain X-8 exhibited its ability to react positively to $66(70.21 \%)$, partially positive to $12(12.77 \%)$ and negatively to $16(17.02 \%)$ out of the 94 different physiological and biochemical traits. X-8 grew on a wide range of sugars (e.g., D-Maltose, D-Trehalose, D-Cellobiose, Gentiobiose, Sucrosea-D-glucose, D-Fructose, Sucrose), polyvalent alcohols (e.g., DSorbitol, D-Mannitol, D-Arabitol, myo-Inositol), hexose-PO4 (e.g., DFructose-6-PO4, D-Fructose-6-PO4), Amino acid (e.g., L-Alanine, LArginine, L-Aspartic Acid, L-Glutamic Acid, L-Serine) and Sodium Lactate. D-Mannose, D-Fructose, Sucrose and D-Maltose, which indicated in the red asterisk in Table 1, can be also utilized by Flavobacterium piscicida (synonymous of $P$. piscicida) described by Bein in 1954 (Bein, 1954).

Based on both ANI (96.23\%) and the high similarity between $16 \mathrm{~S}$ rRNA gene sequences of strain X-8 and Pseudoalteromonas piscicida JCM20779 ${ }^{\mathrm{T}}$, as well as the chemical characterization of strain X-8, it was designated Pseudoalteromonas piscicida X-8.

Bacterial strain re-isolated from the bleaching diseased tissue reinfected by $P$. piscicida X- 8 was identified to be the same bacterium according to its $16 \mathrm{~S}$ rRNA gene sequences. This result conformed to the 
$10 \mathrm{~h}$
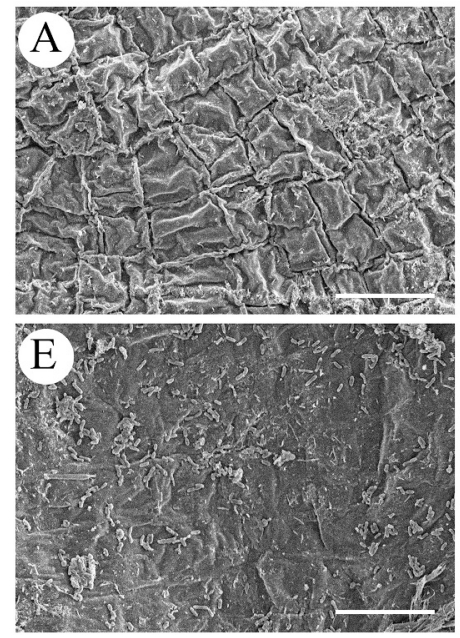

$30 \mathrm{~h}$
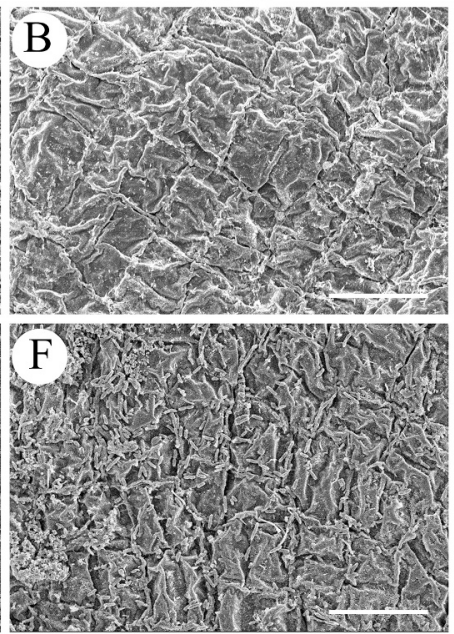

$52 \mathrm{~h}$
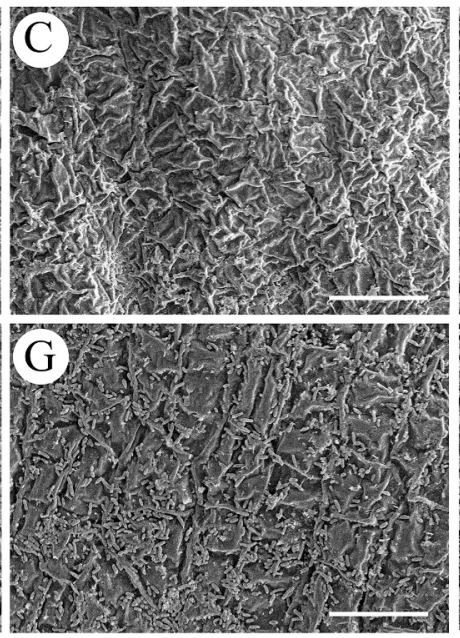

$72 \mathrm{~h}$

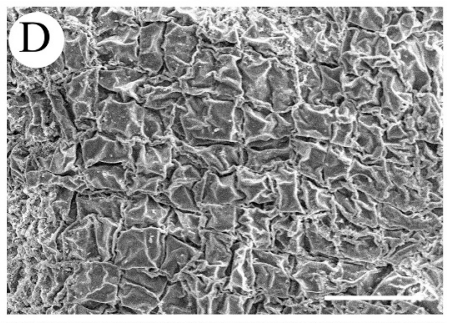

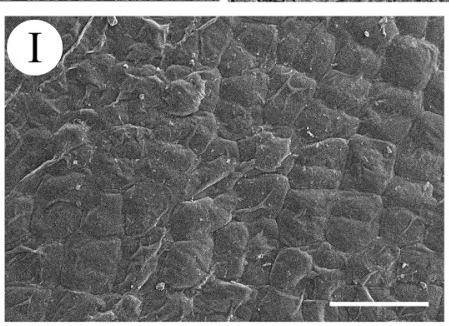

Fig. 3. SEM observations of re-infected tissue by strain $\mathrm{X}-8$.

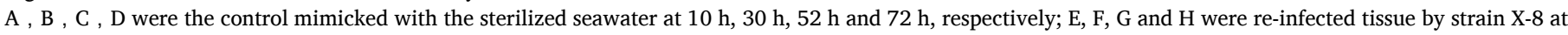
$10 \mathrm{~h}, 30 \mathrm{~h}, 52 \mathrm{~h}$ and $72 \mathrm{~h}$, respectively. I: SEM observations of the normal morphology of surface of healthy juvenile sporophytes.

CW: cell wall; C: chloroplasts; M: mitochondria; N: nucleus. Bars: $30 \mu \mathrm{m}$.

$10 \mathrm{~h}$
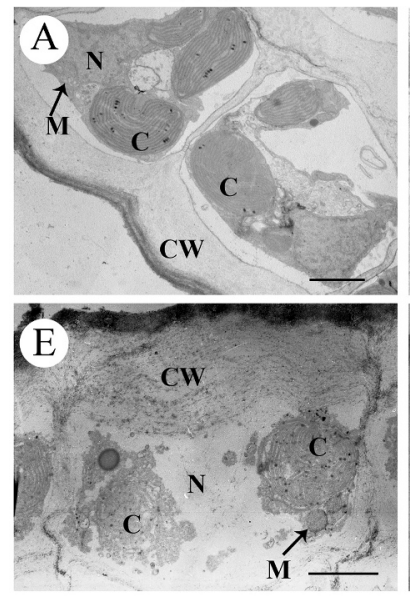

$30 \mathrm{~h}$
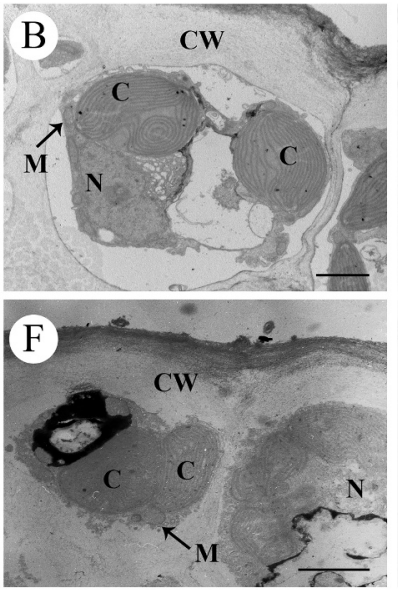

52 h
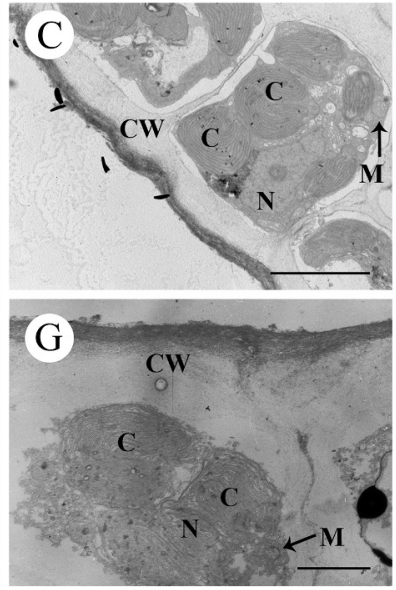

$72 \mathrm{~h}$
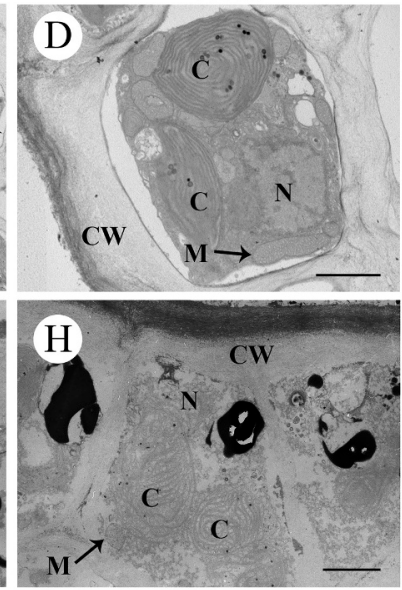

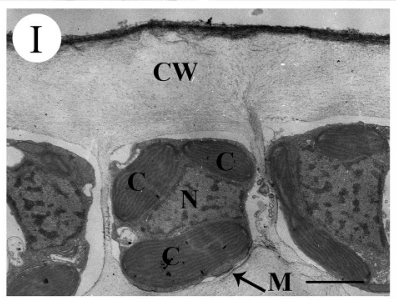

Fig. 4. Ultrastructural changes of infected cells by strain $\mathrm{X}-8$.

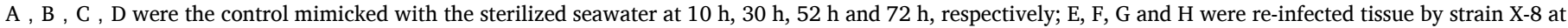

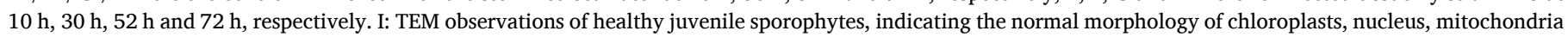
and cell. Black arrows indicated mitochondria.

CW: cell wall; C: chloroplasts; M: mitochondria; N: nucleus. Bars: A, B, D: $2 \mu \mathrm{m}$; C: $5 \mu \mathrm{m}$; E, F, G, H and I: $3.5 \mu \mathrm{m}$. 


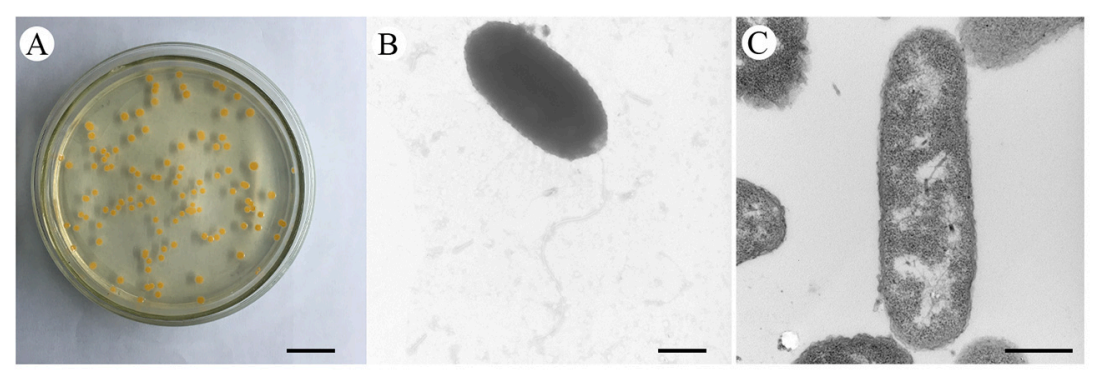

Fig. 5. Morphological characteristics X-8.

A: morphology of strain X-8 colonies on Zobell 2216 E agar media; B and C: morphology of strain X-8 observed by negative staining TEM and by ultrathin section TEM respectively. Bars: $\mathrm{A}=1 \mathrm{~cm}$; $\mathrm{B}=1 \mu \mathrm{m} ; \mathrm{C}=200 \mathrm{~nm}$.

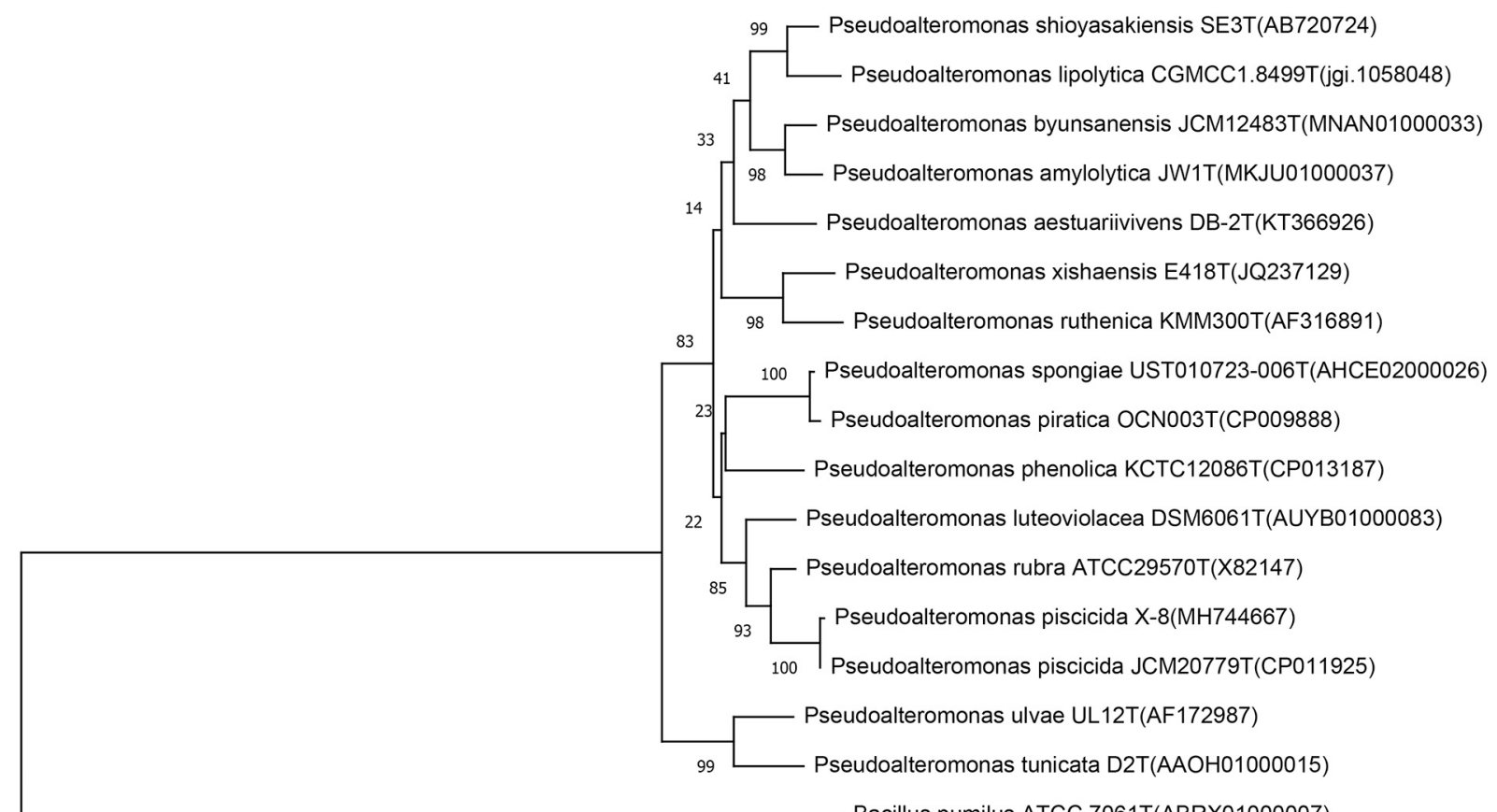

Bacillus pumilus ATCC 7061T(ABRX01000007)

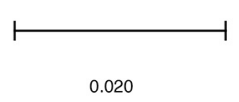

Fig. 6. Neighbour-joining phylogenetic tree based on 16S rRNA gene sequences.

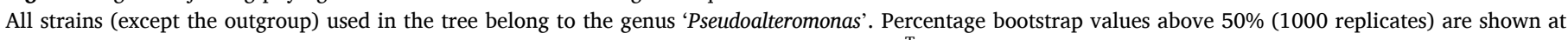
branch nodes. Bar $=0.020$, substitutions per nucleotide position. Bacillus pumilus ATCC $7061^{\mathrm{T}}$ was used as an out group.

Koch's postulates and verified that $P$. piscicida X-8 was the pathogenic bacteria for bleaching disease of $S$. japonica.

\section{Discussion}

In this study, we isolated a pathogenic bacterium X-8 from the bleaching diseased sporelings of $S$. japonica. Strain X-8 resulted in bleaching disease in healthy juvenile sporophytes by re-infection assay in laboratory conditions. Chloroplasts were the firstly responded organelle to X-8 infection, which was the consistent to the previous studies by Wang et al. (2003a, 2003b). Further, the re-isolated bacterial strain in the bleaching diseased healthy juvenile sporophytes was identified as the same strain X-8 by blasting the 16S rRNA gene sequences, which was in compliance with Koch's Postulate. Based on $16 \mathrm{~S}$ rRNA gene sequence, ANI and the chemical characterization of strain X8, we designated X-8 as Pseudoalteromonas piscicida X-8. P. piscicida X-8 was a pathogenic bacterium responsible for the bleaching disease of S. japonica.

Pseudoalteromonas piscicida was initially described as Flavobacterium piscicida by Bein in 1954, which was isolated from a dead fish in the "red tide" waters off the southwest coast of Florida (Bein, 1954). F. piscicida was re-assigned as $P$. piscicida in 1995 based on the phylogenetic analysis of its small subunit ribosomal DNA sequence (Gauthier et al., 1995). So far, there are 102 strains of $P$. piscicida and they are widely distributed in the marine environment (Chen et al., 2020). P. piscicida is an aerobic heterotrophic, flagellated Gram-negative with rod-shape. One of the general characteristics is that most of the strains own yellow pigments (Bowman, 2007). Some strains of $P$. piscicida species have been proven as the pathogenic bacteria for marine organisms (Bein, 1954; Hansen et al., 1965; Meyers et al., 1959). F. piscicida (synonymous of Pseudoalteromonas piscicida) was capable of killing fishes under laboratory conditions (Bein, 1954). P. piscicida showed pathogenic to fish including the fiddler crabs, like Uca pugnas and Uca pugilator (Hansen et al., 1965). Pseudoalteromonas piscicida Cura-d, isolated from the diseased eggs of two damselfish Amphiprion clarkii and Amblyglyphidodon curacao, increased the mortality of the eggs of A. clarkii (Nelson and Ghiorse, 1999). Pseudoalteromonas piscicida O-7, which came from the gut of blue swimming crab Portunus pelagicus, showed pathogenicity against P. pelagicus (Talpur et al., 2011). So far, there have been no documents on $P$. piscicida responsible for seaweed diseases. However, some 
Table 1

Characterization of strain X-8 based on the Biolog Gen III microplate.

\begin{tabular}{|c|c|c|}
\hline \multicolumn{3}{|c|}{ Positive reaction with the following substrate/test } \\
\hline Dextrin & $1 \% \mathrm{NaCl}$ & ${ }_{\mathrm{L}}$-Fucose \\
\hline $\mathrm{D}^{- \text {Mannose }^{\mathrm{a}}}$ & Tetrazolium Blue & $\mathrm{L}^{- \text {Aspartic Acid }}$ \\
\hline Inosine & SodiumLactate & L-Glutamic Acid \\
\hline N-Acetyl-D-Galactosamine & $4 \% \mathrm{NaCl}$ & ${ }_{\mathrm{D}}$-Mannitol \\
\hline Aztreonam & Rifamycin SV & Melibiose \\
\hline Acetoacetic Acid & lincomycin & $\alpha$-Hydroxy-Butyric Acid \\
\hline $\mathrm{L}$-Alanine & L-Malic acid & Gentiobiose \\
\hline$\alpha$-D-Glucose & $8 \% \mathrm{NaCl}$ & D-Galacturonic Acid \\
\hline$\beta$-Hydroxy-D, L-Butyric Acid & Fusidic Acid & myo-Inositol \\
\hline $\mathrm{L}^{- \text {Arginine }}$ & pH 6 & $\begin{array}{l}\mathrm{N}-\text { Acetyl}_{-\mathrm{D}^{-}} \\
\text {Galactosamine }\end{array}$ \\
\hline${ }_{\mathrm{D}}$-Fructose ${ }^{\mathrm{a}}$ & Sucrose $^{\mathrm{a}}$ & $\mathrm{D}$-Sorbitol \\
\hline $\mathrm{D}^{- \text {Glucuronic Acid }}$ & Acetic Acid & $\mathrm{D}^{- \text {Raffinose }}$ \\
\hline 3-Methyl Glucose & $\mathrm{D}^{\text {-Trehalose }}$ & ${ }_{\mathrm{D}}$-Saccharic Acid \\
\hline $\mathrm{D}$-Galactose & ${ }_{\mathrm{D}}$-Serine & Glucuronamide \\
\hline L-Histidine & Gelatin & D-Turanose \\
\hline L-Galactonic Acid Lactone & Potassium Tellurite & Guanidine $\mathrm{HCl}$ \\
\hline N-Acetyl- $\beta$-D-mannosamine & Glycyl-L-Proline & D-Cellobiose \\
\hline D-Arabitol & Tween 40 & $\begin{array}{l}\text { D-Lactic Acid Methyl } \\
\text { Ester }\end{array}$ \\
\hline L-Rhamnose & ${ }_{\mathrm{L}}$-Serine & Glycerol \\
\hline${ }_{\mathrm{D}}$-Fructose-6-PO4 & $\begin{array}{l}\text { N-Acetyl- }{ }^{-}- \\
\text {Glucosamine }\end{array}$ & L-Lactic Acid \\
\hline D-Fucose & $\mathrm{D}^{-}$-Maltose $\mathrm{a}^{\mathrm{a}}$ & $\gamma$-Amino-Butyric Acid \\
\hline D-Glucose-6-PO4 & Propanoic Acid & $\mathrm{a}_{\mathrm{D}}-$-Lactose \\
\hline \multicolumn{3}{|c|}{ Weak positive reaction with the following substrate/test } \\
\hline D-Gluconic Acid & b-Methyl-D-Glucoside & Mucic Acid \\
\hline $\mathrm{L}$-Pyroglutamic Acid & D-Serine & $\alpha$-Keto-Glutaric Acid \\
\hline $\mathrm{D}^{-}$Salicin & Quinic Acid & $\alpha$-Hydroxy- Butyric Acid \\
\hline Stachyose & D-Aspartic Acid & Formic Acid \\
\hline \multicolumn{3}{|c|}{ Negative reaction with the following substrate/test } \\
\hline Pectin & Vancomycin & Niaproof 4 \\
\hline Tetrazolium Violet & Nalidixic Acid & Troleandomycin \\
\hline $\begin{array}{l}\text { p-Hydroxy-Phenylacetic } \\
\text { Acid }\end{array}$ & Minocycline & Sodium Bromate \\
\hline D-Malic Acid & Sodium Butyrate & Methyl Pyruvate \\
\hline Lithium Chloride & pH 5 & \\
\hline Bromo-Succinic Acid & Citric Acid & \\
\hline
\end{tabular}

a Described by Bein (1954).

bacterial species from genus Pseudoaltermonas have been identified as pathogenic bacteria for seaweeds. Pseudoalteromonas bacteriolytica sp. nov. was the pathogenic bacteria causing red spot disease of $S$. japonica (Sawabe et al., 1998). Pseudoalteromonas sp. Y, could produce brominated antibiotic compounds and low molecular weight compounds which could cause rapid cell lysis and death of seaweeds (including Gymnodinium catenatum, Chattonella marina and Heterosigma akashiwo) (Lovejoy et al., 1998). Pseudoalteromonas sp. A25, isolated from the Ariake Sea, Japan, was described with strong algicidal activity (Mitsutani et al., 2001). For the first time our study identifies $P$. piscicida X-8 as a pathogenic bacterium responsible for the bleaching disease of farmed S. japonica.

Nursery stage of farmed $S$. japonica is significantly important, as it plays an important role in supplying the healthy sporelings for the field cultivation. Therefore, controlling disease at nursery stage is the most important task for the nursery farms of $S$. japonica. Isolation and identification of the pathogenic bacteria will be useful for correct diagnosis of seaweed diseases and with regard to disease management preventing and controlling the disease outbreaks. So far, different pathogenic bacteria have been identified for different diseases by merging conventional culture-dependent method and molecular identification by 16S rRNA gene sequences in China. Micrococcus (Wu, 1990) and alginic acid decomposing bacteria (Chen et al., 1979, 1981; Ding, 1990; Liu et al., 2002; Wang et al., 2003a, 2003b) were identified as the pathogenic bacteria for the malformation disease and the green rot disease/fallingoff of sporelings of $S$. japonica at the nursery stage respectively. In our study, bleaching disease was first reported in sporelings of $S$. japonica at nursery stage. Isolation and identification of pathogenic bacteria of $P$. piscicida X-8 enriched the pathogenic bacterial information in the list of economically important farmed seaweeds.

Till date, research on the diseases of farmed $S$. japonica is still in its infancy. Disease outbreaks are the interactions of environmental factors (temperature, light intensity etc.), the defense ability of the host, and the presence of pathogenic bacteria (Egan et al., 2014). This undoubtedly increases the difficulty of pathological research of farmed $S$. japonica. Additionally, the isolation and identification of the pathogenic bacteria for farmed $S$. japonica is also difficult. The reason may include the followings: (1) most of the pathogenic bacteria of seaweeds are opportunistic pathogenic bacteria which exhibit pathogenic virulence only under certain conditions (Wang et al., 2014). (2) the pathogenic bacteria of $S$. japonica can rarely be successful cultured in vitro, most of them are unculturable (Zhang et al., 2020; Wang et al., 2021; Prof. Gaoge Wang's pers. communication). (3) the disease of $S$. japonica may be due to the combined effect of multiple pathogenic bacteria (Gaoge Wang's personal communications). Therefore, there will still be a long way to go for determining pathogenic bacteria for the cultivated S. japonica.

\section{Conclusions}

S. japonica is one of the commercially important seaweeds all over the world. Like the land crops, disease outbreaks occur at both nursery stage and field cultivation, which causes severe economic loss. Disease outbreaks change at different cultivating years because of the complicated interactions of the cultivation environment, the host $S$. japonica and the opportunistic pathogenic bacteria. This makes it difficult to trace the pathogenic bacteria for the same disease. Therefore, isolation and identification of the pathogenic bacteria are still a bottleneck issue for the farmed $S$. japonica. However, identification of pathogenic bacteria is of primary importance for disease diagnosis and disease control, especially for the nursery stage. In this study, $P$. piscicida X-8 was identified as the pathogenic bacterium for the bleaching disease of $S$. japonica. Our results enrich the list of pathogenic bacteria for the farmed seaweeds and will help to establish a stable seaweed-pathogenic bacteria experimental model to further elucidate the virulence mechanisms. This will help to develop appropriate disease management to effectively prevent and mitigate the occurrence of bleaching disease of $S$. japonica at nursery stage.

\section{Author statement}

We have revised our manuscript carefully according to the two reviewers' comments. All the authors fully agree on the revisions.

\section{Declaration of Competing Interest}

The authors declare that they have no conflict of interest.

\section{Acknowledgements}

This study was sponsored by the Marine S \& T Fund of Shandong Province for Pilot National Laboratory for Marine Science and Technology (Qingdao) (2018SDKJ0406-5), the National Natural Science Foundation of China (42076106; 41576158); National Key R\&D Program of China (2018YFD0900305); Fundamental Research Funds for the Central Universities (201822025).

\section{References}

Bein, S.J., 1954. A study of certain chromogenic bacteria isolated from "Red Tide" water with a description of a new species. Bull. Mar. Sci. 4, 110-119.

Bowman, J.P., 2007. Bioactive compound synthetic capacity and ecological significance of marine bacterial genus Pseudoalteromonas. Mar. Drugs 5, 220-241. https://doi. org/10.3390/md504220. 
Chen, X.L., Wang, Y., Wang, P., Zhang, Y., 2020. Proteases from the marine bacteria in the genus Pseudoalteromonas: diversity, characteristics, ecological roles, and application potentials. Mar. Life Sci. Technol. 2, 309-323. https://doi.org/10.1007/ s42995-020-00058-8.

Chen, D., Lin, G., Shen, S., 1979. Studies on alginic acid decomposing bacteria I. Action of alginic acid decomposing bacteria and alginase on Laminaria japonica. Oceanol. Limnol. Sin. Deep Sea Res. B 10, 329-333. https://doi.org/10.1016/0198-0254(80) 96058-6.

Chen, D., Lin, G., Shen, S., 1981. Studies on alginic acid decomposing bacteria II. Rot disease of Laminaria summer sporelings caused by alginic acid decomposing bacteria. Oceanol. Limnol. Sin. 12, 133-137.

Ding, M.L., 1990. Effect of environmental factors on alginic acid decomposing bacteria leading to disease and decay of kelp. Acta Oceanol. Sinica 12, 224-229 (In Chinese with English abstract).

Ding, M., 1992. The effects of the environmental factors on Laminaria disease caused by alginic acid decomposing bacteria. Acta Oceanol. Sin. 11, 123-130 (doi:CNKI:SUN SEAE.0.1992-01-010).

Egan, S., Harder, T., Burke, C., Steinberg, P., Kjelleberg, S., Thomas, T., 2013. The seaweed holobiont: understanding seaweed-bacteria interactions. FEMS Microbiol. Rev. 37, 462-476. https://doi.org/10.1111/1574-6976.12011.

Egan, S., Fernandes, N.D., Kumar, V., Gardiner, M., Thomas, T., 2014. Bacterial pathogens, virulence mechanism and host defence in marine macroalgae. Environ. Microbiol. 16, 925-938. https://doi.org/10.1111/1462-2920.12288.

FAO, 2016. The State of World Fisheries and Aquaculture 2016 (SOFIA): Contributing to Food Security and Nutrition for All, 4. State of World Fisheries \&Aquaculture, pp. 40-41. https://doi.org/10.2983/0730-8000(2006)25[129:CODACI]2.0.CO;2.

Gachon, C.M., Sime-Ngando, T., Strittmatter, M., Chambouvet, A., Kim, G.H., 2010. Alga diseases: spotlight on a black box. Trends Plant Sci. 15, 633-640. https://doi.org/ 10.1016/j.tplants.2010.08.005.

Gauthier, G., Gauthier, M., Christen, R., 1995. Phylogenetic analysis of the genera Alteromonas, Shewanella, and Moritella using genes coding for small-subunit rRNA sequences and division of the genus Alteromonas into two genera, Alteromonas (emended) and Pseudoalteromonas gen. nov., and proposal of twelve new species combinations. Int. J. Syst. Bacteriol. 45, 755-761. https://doi.org/10.1099/ 00207713-45-4-755.

Hansen, A.J., Weeks, O.B., Colwell, R.R., 1965. Taxonomy of Pseudomonas Piscicida (Bein) Buck, Meyers, and Leifson. J. Bacteriol. 89, 752-761. https://doi.org/ 10.1128/JB.89.3.752-761.1965.

Hudson, J., Gardiner, M., Deshpande, N., Egan, S., 2018. Transcriptional response of Nautella italica R11 towards its macroalgal host uncovers new mechanisms of hostpathogen interaction. Mol. Ecol. 27, 1820-1832. https://doi.org/10.1111/ mec.14448.

Khalifa, A.Y.Z., Bekhet, G., 2017. First isolation and characterization of the pathogenic Aeromonas veronii bv. veronii associated with ulcerative syndrome in the indigenous Pelophylax ridibundus of Al-Ahsaa, Saudi Arabia. Microb. Pathog. 117, 361-368. https://doi.org/10.1016/j.micpath.2017.10.019.

Kimura, M., 1980. A simple method for estimating evolutionary rates of base substitutions through comparative studies of nucleotide sequences. J. Mol. Evol. 16 111-120. https://doi.org/10.1007/BF01731581.

Kumar, S., Stecher, G., Li, M., Knyaz, C., Tamura, K., 2018. MEGA X: molecular evolutionary genetics analysis across computing platforms. Mol. Biol. Evol. 35, 1547-1549. https://doi.org/10.1093/molbev/msy096.

Larkin, M.A., Blackshields, G., Brown, N.P., Chenna, R., McGettigan, P.A., McWilliam, H., Valentin, F., Wallace, I.M., Wilm, A., Lopez, R., Thompson, J.D., Gibson, T.J., Higgins, D.G., 2007. Clustal W and Clustal X version 2.0. Bioinformatics 23, 2947-2948. https://doi.org/10.1093/bioinformatics/btm404.

Liu, C.S., Wang, L.L., Wang, M., Tang, X.X., 2002. Difference analysis of infection activity of alginic acid decomposing bacteria infecting Laminaria japonica (in Chinese with English abstract). Mar. Sci. 26, 1-2.

Lovejoy, C., Bowman, J.P., Hallegraeff, G.M., 1998. Algicidal effects of a novel marine Pseudoalteromonas isolate (class Proteobacteria, gamma subdivision) on harmful algal bloom species of the genera Chattonella, Gymnodinium, and Heterosigma. Appl. Environ. Microbiol. 64, 2806-2813. https://doi.org/10.1128/AEM.64.8.28062813.1998.

Maurin, N., Gourret, J.P., Tivoli, B.J.A., 1993. Histopathology of the interaction between Ascochyta fabae and Vicia faba: comparison of susceptible and resistant reactions. Agronomie 13, 921-927. https://doi.org/10.1051/agro:19931006.

Melissa, G., Torsten, T., Egan, S., 2015a. A glutathione peroxidase (GpoA) plays a role in the pathogenicity of Nautella italica strain R11 towards the red alga Delisea pulchra. FEMS Microbiol. Ecol. 91. https://doi.org/10.1093/femsec/fiv021.

Melissa, G., Neil, D.F., Dennis, N., Mark, R., Staffan, K., Zhong, L., Torsten, T., Egan, S., 2015b. VarR controls colonization and virulence in the marine macroalgal pathogen Nautella Italica R11. Front. Microbiol. 6, 1130. https://doi.org/10.3389/ fmicb.2015.01130.

Meyers, S.P., Baslow, M.H., Bein, S.J., Marks, C.E., 1959. Studies of Flavobacterium piscicida Bein. I. Growth, toxicity, and ecological considerations. J. Bacteriol. 78, 225-230. https://doi.org/10.1128/JB.78.2.225-230.1959.

Mitsutani, A., Yamasaki, I., Kitaguchi, H., Kato, J., Ueno, S., Ishida, Y., 2001. Analysis of algicidal proteins of a diatom-lytic marine bacterium Pseudoalteromonas sp. strain
A25 by two-dimensional electrophoresis. Phycologia 40, 286-291. https://doi.org/ 10.2216/i0031-8884-40-3-286.1.

Neil, F., Rebecca, J.C., Sharon, R.L., Mohammad, R.S., Peter, D.S., Staffan, K., Torsten, T., 2011. Genomes and virulence factors of novel bacterial pathogens causing bleaching disease in the marine red alga Delisea pulchra. PLoS One 6, e27387. https://doi.org/ 10.1371/journal.pone.0027387.

Nelson, E.J., Ghiorse, W.C., 1999. Isolation and identification of Pseudoalteromonas piscicida strain Curad associated with diseased damselfish (Pomacentridae) eggs. J. Fish Dis. 22, 253-260. https://doi.org/10.1046/j.1365-2761.1999.00168.x.

Oppenheimer, C.H.J., 1952. The growth and viability of sixty-three species of marine bacteria as influenced by hydrostatic pressure. J. Mar. Res. 11 (1), 10-18.

Richter, M., Rossello-Mora, R., Glockner, F.O., Peplies, J., 2015. JSpeciesWS: a web server for prokaryotic species circumscription based on pairwise genome comparison. Bioinformatics. 32, 929-931. https://doi.org/10.1093/bioinformatics/ btv681.

Saitou, N., Nei, M., 1987. The neighbor-joining method: a new method for reconstructing phylogenetic trees. Mol. Biol. Evol. 4, 406-425. https://doi.org/10.1093/ oxfordjournals.molbev.a040454.

Sawabe, T., Hideyuki, M., Masahiro, T., Kazuaki, N., Kenichi, T., Mohammed, M.I., Isao, Y., Yoshio, E., Richard, C., 1998. Pseudoalteromonas bacteriolytica sp. nov., a marine bacterium that is the causative agent of red spot disease of Laminaria japonica. Int. J. Syst. Bacteriol. 48, 769-774. https://doi.org/10.1099/00207713-483-769.

Sun, X., He, Y., Xu, N., Xia, Y., Liu, Z., 2012. Isolation and identification of two strains of pathogenic bacteria and their effects on the volatile metabolites of Gracilariopsis lemaneiformis (Rhodophyta). J. Appl. Phycol. 24, 277-284. https://doi.org/10.1007/ s10811-011-9677-0.

Talpur, A.D., Memon, A.J., Ikhwanuddin, M., Daniel, M.M.D., Abol-Munafi, A.B., 2011. Pathogenicity and antibiotic sensitivity of pathogenic flora associated with the gut of blue swimming crab, Portunus pelagicus (Linnaeus, 1758). J. Anim. Vet. Adv. 10, 2016-2119. https://doi.org/10.3923/javaa.2011.2106.2119.

Tseng, C.K., 1962. Manual of Cultivation of Haidai (Laminaria Japonica) (in Chinese), $99-$ 122. Science Press, Beijing, pp. 146-154.

Tseng, C.K., 1985. Manual of Cultivation of Seaweeds (in Chinese). Shanghai Science and Technics Press, Shanghai, pp. 82-96.

Tseng, C.K., 1994. Anthology of Tseng Cheng-Kui, 1. Ocean Press, Beijing, pp. 871-873.

Vairappan, C.S., Suzuki, M., Motomura, T., Ichimura, T., 2001. Pathogenic bacteria associated with lesions and thallus bleaching symptoms in the Japanese kelp Laminaria religiosa Miyabe (Laminariales, Phaeophyceae). Hydrobiologia 445, 183-191. https://doi.org/10.1023/A:1017517832302.

Wang, F., Li, M., Huang, L., Zhang, X.-H., 2021. Cultivation of uncultured marine microorganisms. Mar. Life Sci. Technol. 3, 117-120. https://doi.org/10.1007/ s42995-021-00093-Z.

Wang, G., Liu, X., Li, X., Lin, W., Yan, X., Duan, D., 2003a. Spatial-temporal changes of $\mathrm{Ca}^{2+}$ distribution in cells of Laminaria japonica infected by alginic acid degradation bacteria. Chin. J. Oceanol. Limnol. 9, 36-42 (In Chinese with English abstract).

Wang, L., Tang, X., Wang, M., Zhang, P., 2003b. The roles played by alginic acid decomposing bacteria during the time of green decay disease of Laminaria japonica. J. Ocean Univ. Qingdao 33, 245-248.

Wang, G., Lu, B., Shuai, L., Li, D., Zhang, R., 2014. Microbial diseases of nursery and field-cultivated Saccharina japonica (Phaeophyta) in China. Algol. Stud. 145/146, 39-51. https://doi.org/10.1127/1864-1318/2014/0167.

Weinberger, F., Friedlander, M., Gunkel, W., 1994. A bacterial facultative parasite of Gracilaria conferta. Dis. Aquat. Org. 18, 135-141. https://doi.org/10.3354/ dao018135.

Weinberger, F., Hoppe, H.G., Friedlander, M., 1997. Bacterial induction and inhibition of a fast necrotic response in Gracilaria conferta (Rhodophyta). J. Appl. Phycol. 9, 277-285. https://doi.org/10.1023/A:1007990712925.

Weisburg, William G., Barns, S.M., Pelletier, Dale A., Lane, David J., 1991. 16S ribosomal DNA amplification for phylogenetic study. J. Bacteriol. 173, 697-703. https://doi. org/10.1128/jb.173.2.697-703.1991.

Wu, C.Y., 1990. Cultivation of temperate seaweeds in the Asia Pacifi c region. In: Regional Workshop on the Culture and Utilization of Seaweeds, Cebu City, pp. 27-31.

Xiang, J., 2001. Disease Occurrence and Control Strategies of Mariculture Organisms. Ocean Press, Beijing, pp. 78-83.

Ying, J.J., Zhang, S.L., Huang, C.Y., Xu, L., Zhao, Z., Wu, M., Sun, C., 2019. Algicoccus marinus gen. nov. sp. nov., a marine bacterium isolated from the surface of brown seaweed Laminaria japonica. Arch. Microbiol. 201, 943-950. https://doi.org/ 10.1007/s00203-019-01664-6.

Zhang, J.C., Suo, R.Y., Zhang, D.M., 1962. Disease and pests in haidai (Laminaria japonica) cultivation. In: Tseng, C.K., Wu, C.Y. (Eds.), Manual of Cultivation of Haidai (Laminaria japonica). Science Press, Beijing, pp. 230-236 in Chinese.

Zhang, R., Chang, L., Xiao, L., Zhang, X., Han, Q., Li, N., Egan, S., Wang, G., 2020. Diversity of the epiphytic bacterial communities associated with commercially cultivated healthy and diseased Saccharina japonica during the harvest season. J. Appl. Phycol. 32, 2071-2080. https://doi.org/10.1007/s10811-019-02025-y. 